\title{
Effects of Inorganic Seed Aerosol on the Formation of Nitrogen-Containing Organic Compounds from Reaction of Ammonia with Photooxidation Products of Toluene
}

\author{
Jun $\mathrm{Xu}^{1}$, Mingqiang Huang ${ }^{1 *}$, Zhuangzhuang Feng ${ }^{1}$, Shunyou Cai ${ }^{1}$, \\ Weixiong $\mathrm{Zhao}^{2}$, Changjin $\mathrm{Hu}^{2}$, Xuejun $\mathrm{Gu}^{2}$, Weijun $\mathrm{Zhang}^{2 * *}$
}

${ }^{1}$ Fujian Provincial Key Laboratory of Modern Analytical Science and Separation Technology, College of Chemistry and Chemical Engineering and Environment, Minnan Normal University, Zhangzhou, China ${ }^{2}$ Laboratory of Atmospheric Physico-Chemistry, Anhui Institute of Optics and Fine Mechanics, Chinese Academy of Sciences, Hefei, China

Received: 10 November 2018

Accepted: 3 March 2019

\begin{abstract}
Ammonia $\left(\mathrm{NH}_{3}\right)$ is the most important alkaline pollution gas in the atmosphere, and the nitrogen-containing organic compounds formed by photooxidation with toluene is the main component of atmospheric brown carbon $(\mathrm{BrC})$. Inorganic seed aerosols such as ammonium sulfate and calcium chloride can affect the formation and chemical composition of secondary organic aerosol (SOA), because of their large surface area. The effects of seed aerosols with different ingredients, concentrations, humidity and acidity on the formation of nitrogen-containing organic compounds were studied qualitatively by UV-Vis spectrometry in this study. The results showed that inorganic seed aerosols promoted the formation of nitrogen-containing organic compounds. The order of promotion is calcium chloride $>$ sodium silicate $>$ ammonium sulfate $>$ sodium chloride $>$ ammonium nitrate. The formation concentration of nitrogen-containing organic products gradually increases with the increase of calcium chloride seed aerosol concentration and acidity. When the seed aerosol is alkaline, it is not conducive to its formation. The increase of water molecules would reduce the concentration of nitrogen-containing organic products as the relative humidity increases. These would provide new experimental basis for the formation mechanism of brown carbon of aromatic SOA.
\end{abstract}

Keywords: smog chamber, ammonia, toluene secondary organic aerosol, inorganic seed aerosol, nitrogen-containing organic compounds

*e-mail: huangmingqiang@mnnu.edu.cn

**e-mail: wjzhang@aiofm.ac.cn 


\section{Introduction}

Secondary organic aerosols (SOAs) are semi-volatile and non-volatile products formed from the reaction of volatile organic compounds (VOCs) emitted from biological or anthropogenic sources into the atmosphere with oxidants such as hydroxyl radicals $(\mathrm{OH} \bullet)$, nitrate radicals $\left(\mathrm{NO}_{3} \cdot\right)$, and ozone $\left(\mathrm{O}_{3}\right)$. These products are liquid and solid particles suspended in the atmosphere formed by their own condensation or gas/particle state distribution, and their particle size is usually less than $2.5 \mu \mathrm{m}$, which is an important component of atmospheric fine particlate matter $\left(\mathrm{PM}_{2.5}\right)$ [1-2]. Ammonia $\left(\mathrm{NH}_{3}\right)$ derived from agricultural sources and motor vehicle exhaust is the primary alkaline pollution gas in the atmosphere [3-4], except that it can react with acid gases such as sulfur dioxide $\left(\mathrm{SO}_{2}\right)$ and nitrogen oxides (NOx) in the presence of water vapor to form sulfates and nitrates [5-6]. $\mathrm{NH}_{3}$ can also react with carboxylic acid and dialdehyde components of SOA to form organic acid ammonium and imidazole nitrogencontaining organic compounds (NOC) [7-8]. These nitrogen-containing products have strong polarity, hygroscopicity and solubility, and can have important effects on the optical and physicochemical properties of aerosol particles, atmospheric visibility and human health [9-10]. The chemical composition and formation mechanism of nitrogen-containing organic compounds have become the focus of current research in the field of atmospheric chemistry.

In the process of SOA formation, if there are background particles, it will usually become the condensation, adsorption/absorption center required for the agglomeration process, and the particles with this effect are called seed aerosols [11]. Studies have shown that the formation of SOA is closely related to reactant concentration, illumination time, temperature and humidity, and seed aerosol [12]. Inorganic fine particles such as ammonium sulfate $\left(\left(\mathrm{NH}_{4}\right)_{2} \mathrm{SO}_{4}\right)$ and calcium chloride $\left(\mathrm{CaCl}_{2}\right)$ present in the atmosphere were used as seed aerosols because of their relatively large surface area, and become the site for condensation of the photooxidation products of VOCs [13-14]. For example, in the laboratory simulation process, Edney et al. [15] and Hao et al. [16] added $\left(\mathrm{NH}_{4}\right)_{2} \mathrm{SO}_{4}$ seed aerosol to the SOA system formed from the photooxidation of toluene. Although it has been observed that seed aerosol has no remarkable effect on the yield of SOA, seed aerosol promotes the formation of SOA in the initial stage of the reaction, reducing the time required to reach the gas/particle state balance. In addition, the inorganic seed aerosol also has a catalytic effect that causes a heterogeneous reaction of the aldehyde compound of the photooxidation product, thereby changing the chemical composition of the SOA. Kroll et al. [17] and $\mathrm{Lu}$ and his cooperator [18] found that acidic $\left(\mathrm{NH}_{4}\right)_{2} \mathrm{SO}_{4}$ seed aerosol heterogeneously catalyze the hydration, aldol condensation and polymerization of aldehydes, such as glyoxal and methylglyoxal, to form less volatile hemiacetals, acetals and polymers. Thereby, the yield of m-xylene SOA is remarkably improved. Chu et al. [19] found that the yield of toluene SOA decreased because of the heterogeneous reduction reaction of ferrous sulfate $\left(\mathrm{FeSO}_{4}\right)$ seed aerosol with the photooxidation products of toluene to form volatile products. Therefore, when inorganic seed aerosol is present in the reaction system, the formation of nitrogen-containing organic compounds would be affected. However, the effects of inorganic seed aerosol on the formation of nitrogen-containing organic compounds have not been reported.

With the rapid development of China's economy, urban air pollution is also becoming more and more serious, and the urban atmosphere contains a relatively high concentration of inorganic fine particles. For example, the average annual $\mathrm{PM}_{2.5}$ particle concentration in Beijing is $100 \mu \mathrm{g} \bullet \mathrm{m}^{-3}$, and exceeds $300 \mu \mathrm{g} \bullet \mathrm{m}^{-3}$ in dust and haze days, one-third of the $\mathrm{PM}_{2.5}$ particles are inorganic fine particles. Sodium silicate and $\mathrm{CaCl}_{2}$ are the main components of inorganic aerosol particles dust days, while $\left(\mathrm{NH}_{4}\right)_{2} \mathrm{SO}_{4}$ and sodium nitrate $\left(\mathrm{NaNO}_{3}\right)$ are important components of inorganic fine particles in haze days [20-21]. Our group has used the smog chamber system to explore the effect of $\mathrm{NH}_{3}$ on the formation of SOA formed from the photooxidation products of toluene and other monoaromatic hydrocarbons. The reaction products were characterized by UV-visible spectroscopy, infrared spectroscopy and time-of- flight mass spectrometry. The series of characteristic mass spectral peaks $\mathrm{C}_{\mathrm{x}} \mathrm{H}_{\mathrm{y}} \mathrm{N}_{\mathrm{n}}^{+}$of imidazole nitrogen-containing organic compounds of aromatic SOA were obtained, and it was confirmed that imidazole nitrogen-containing compounds formed from the heterogeneous reaction of $\mathrm{NH}_{3}$ and dicarbonyl components of aromatic SOA [2224]. On this basis, this paper continues to study the effects of different ingredients, concentrations, humidity and acidity of seed aerosol on the formation of nitrogencontaining organic compounds formed from the reaction of $\mathrm{NH}_{3}$ with the photooxidation products of toluene. These would provide a new experimental basis for the formation mechanism of brown carbon of aromatic SOA.

\section{Experimental}

\section{Materials}

Toluene $(\geq 99.0 \%)$ was obtained from Shantou Dahao Fine Chemical Co., Ltd. Methanol ( $\geq 99.0 \%)$ was purchased from Sigma-Aldrich Chemistry Corporation, Germany. Ammonia $(\geq 99.0 \%)$, ammonium sulfate ( $\geq 99.0 \%$ ), ammonium nitrate $(\geq 99.0 \%$ ), calcium chloride ( $\geq 96.0 \%$ ), codium chloride ( $\geq 99.5 \%$ ), sodium silicate $(19.3 \% \sim 22.8 \%)$, hydrochloric acid $(36.0 \% \sim 38.0 \%)$, and ethanol $(\geq 99.7 \%)$ were obtained from Xilong Chemical Co., Ltd. Sodium hydroxide $(\geq 96.0 \%)$ was purchased from Sinopharm Chemical Reagent Co., Ltd. 
Ozone was generated by an ozone generator (Qingdao Xinmei Purification Equipment Co., Ltd.)

\section{Smog Chamber Experiment}

Inorganic seed aerosol experiments were carried out in a homemade smog chamber system. The device is mainly composed of four parts, namely the zero air generation system, sample injection system, photoreaction system and product collection and detection system. The compressed air produced by the air compressor was passed through activated charcoal, color-changing silica gel and a Balston DFU-Grade BX filter to remove hydrocarbon compounds, moisture and suspended particulates to obtain the zero air required for the experiment. The zero air passes through a 250 $\mathrm{mL}$ reactant liquid vaporization bottle and enters a 400 $\mathrm{L}$ chamber made of Teflon material having a thickness of $0.1 \mathrm{~mm}$. The temperature, pressure and relative humidity in the smog chamber was about $25^{\circ} \mathrm{C}, 101 \mathrm{MPa}$ and $37 \% \pm 5 \%$, respectively. Before each experiment, zero air was used to clean the chamber three times, then about $1 / 3 \sim 1 / 2$ volume of zero air was filled into the chamber. Inorganic seed aerosol was produced by aspirating the salt solution with an atomizing aerosol generator (TSI 9302) at 12 PSI pressure and delivered to the smog chamber for a period of time. Toluene, $\mathrm{O}_{3}$ and $\mathrm{NH}_{3}$ were then injected into the liquid vaporization bottle and filled to the chamber with zero air. The concentration of aerosol particles (inorganic seed aerosol or SOA particles), toluene, $\mathrm{O}_{3}$ and $\mathrm{NH}_{3}$ in the chamber was measured by a scanning mobility particle sizer (SMPS; TSI 3080L DMA, TSI 3775 CPC), GC-FID (Agilent 7820A, USA), $\mathrm{O}_{3}$ analyzer (TEI model 49i), and $\mathrm{NH}_{3}$ analyzer (TEI model 17i), respectively. The concentrations of toluene, $\mathrm{O}_{3}$ and $\mathrm{NH}_{3}$ in the chamber were fixed at $10 \mathrm{ppm}, 50 \mathrm{ppm}$ and $10 \mathrm{ppm}$ in full volume for all the experiments. The photochemical reaction was initiated by turning on four UV lamps with a characteristic wavelength of $254 \mathrm{~nm}$. When $\mathrm{O}_{3}$ is irradiated by ultraviolet light with a wavelength of $254 \mathrm{~nm}, \mathrm{OH} \bullet$ are generated to initiate photooxidation of toluene to form SOA particles, and SOA particles react with $\mathrm{NH}_{3}$ to formed nitrogen-containing organic compounds. After 2 hours of photoreaction, the products were collected at a flow rate of $4 \mathrm{~L} \cdot \mathrm{min}^{-1}$ for 2 hours using a gas cylinder containing $10 \mathrm{~mL}$ of a $3 \%$ methanol solution. Each experiment was performed in parallel three times, and the average of the results of the three experiments was used as the final data.

\section{Experimental Methods}

In order to explore the effect of inorganic seed aerosol with different ingredients, concentrations, relative humidity and acidity on the reaction of $\mathrm{NH}_{3}$ with the photooxidation products of toluene to form nitrogen-containing organic products, the experiment adopted the method of changing each single factor and keeping other conditions unchanged. In the inorganic seed aerosol experiment of different components, five inorganic salts commonly found in the polluted atmosphere were selected as experimental objects. They are calcium chloride $\left(\mathrm{CaCl}_{2}\right.$, strong acid and weak base salt, the main inorganic salt component of the haze days), sodium chloride ( $\mathrm{NaCl}$, strong acid and base salt, the main inorganic salt component of sea salt aerosol), ammonium sulfate $\left(\left(\mathrm{NH}_{4}\right)_{2} \mathrm{SO}_{4}\right.$, strong acid weak base salt, the main inorganic salt component of haze days), ammonium nitrate $\left(\mathrm{NH}_{4} \mathrm{NO}_{3}\right.$, strong acid weak base salt, main inorganic salt component of haze days) and sodium silicate $\left(\mathrm{Na}_{2} \mathrm{SiO}_{3}\right.$, strong base weak acid salt, main inorganic salt component of dusty days). After the above inorganic salts are sequentially formulated into a $4 \mathrm{~g} \cdot \mathrm{L}^{-1}$ salt solution, inorganic seed aerosol particles of $10 \mathrm{~nm}$ to $2000 \mathrm{~nm}$ are generated by the atomizing aerosol generator (TSI 9302) at a pressure of 12 PSI, and then introduced into the chamber for a certain period of time. Its concentration in the chamber is about 120 $\mu \mathrm{g} \cdot \mathrm{m}^{-3}$ in full volume. For the experiment of $\mathrm{CaCl}_{2}$ seed aerosol concentration, the concentration of seed aerosol in the chamber was changed by controlling the passage time of seed particles generated by TSI 9302, which were sequentially set to about $10,20,40,80,120,160$, and $200 \mu \mathrm{g}^{-3} \mathrm{~m}^{-3}$. In the experiment of relative humidity of $\mathrm{CaCl}_{2}$ seed aerosol, the concentration of seed aerosol in the chamber was kept at $120 \mu \mathrm{g} \bullet \mathrm{m}^{-3}$, and the relative humidity in the chamber was regulated by changing the time when the zero air through a sparger was immersed in deionized water. The humidity was adjusted to about $37 \%, 53 \%, 61 \%, 79 \%$, and $87 \%$, respectively. For the seed aerosol acidity experiment, the $\mathrm{pH}$ values of the $\mathrm{CaCl}_{2}$ solution were adjusted to $1,3,5,7,9,11$ and 13 by using hydrochloric acid (HCI) and sodium hydroxide $(\mathrm{NaOH})$ solution, respectively, and seed particles were generated by TSI 9302 and then introduced into the chamber to make its concentration in the chamber $120 \mu \mathrm{g} \cdot \mathrm{m}^{-3}$ in full volume. In all experiments, the concentrations of toluene, $\mathrm{O}_{3}$, and $\mathrm{NH}_{3}$ in the chamber were kept constant at 10,50 and $10 \mathrm{ppm}$, respectively, and illuminated with four UV lamps for 2 hours.

After the end of the photoreaction of each experiment, the chemical composition of the SOA particles were measured online using an aerosol laser time-of-flight mass spectrometer (ALTOFMS). The SOA particles passed through the inlet system and the particle sizing system, then entered the vacuum chamber of the mass spectrometer, where they were desorbed and ionized by a $248 \mathrm{~nm} \mathrm{KrF}$ laser, and the generated ions were detected by a time-of-flight mass spectrometer in order to obtain the mass spectrum of all ions generated by laser ionization. The chemical composition of aerosol particles is gained from the ion peaks in the mass spectrum. Also, after the completion of the photoreaction, the products were collected with a 3\% methanol solution for the UV-Vis spectrometric measurement as provided in our previous studies [23-24]. 


\section{Results and Discussion}

Previous chamber experiments have shown that $\mathrm{OH}$-initiated photooxidation of toluene and other monoaromatic hydrocarbons generate semi-volatile and low-volatile aldehydes and ketones, such as benzaldehyde, glyoxal, methylglyoxal, benzoic acid, glyoxylic acid and methylglyoxylic acid. These products can form SOA particles by nucleation or gas/particle conversion [25-27]. When a certain amount of $\mathrm{NH}_{3}$ and seed aerosol is present in the reaction system, it will affect the formation process and composition of the product. When the photoreaction of each experiment was completed, the SOA particles were measured by ALTOFMS. The laser time-of-flight mass spectrum of toluene SOA particles in the presence of $\mathrm{CaCl}_{2}$ seed aerosol is shown in Fig. 1, and the mass spectrum of SOA particles with other inorganic seed aerosol is similar to that shown in Fig. 1. The mass spectrum peak with the highest peak intensity of $\mathrm{m} / \mathrm{z} 41\left(\mathrm{C}_{2} \mathrm{H}_{2} \mathrm{~N}^{+}\right)$, along with $\mathrm{m} / \mathrm{z} 67 \quad\left(\mathrm{C}_{3} \mathrm{H}_{3} \mathrm{~N}_{2}^{+}\right)$and $28\left(\mathrm{CH}_{2} \mathrm{~N}^{+}\right)$are the characteristic cracking peaks of the imidazole compounds, indicating that the nitrogen-containing imidazole organic compounds are the main reaction product [22-24]. In addition, in the mass spectrum, the fragment peak of m/z 18 corresponds to the ammonium ion $\left(\mathrm{NH}_{4}^{+}\right)$, and $\mathrm{m} / \mathrm{z} 44$ is the fragment peak $\left(\mathrm{COO}^{+}\right)$ after the carboxyl group (-COOH) of the organic acid compound loses the hydrogen atom. These confirm that ammonium carboxylates are formed during the photoreaction in the presence of $\mathrm{NH}_{3}$ and seed aerosol.

The product solutions of all the experiments were measured by an ultraviolet-visible spectrometer. UVvisible absorption spectrum of toluene SOA particles in the presence of $\mathrm{CaCl}_{2}$ seed aerosol is displayed in Fig. 2, and the absorption spectrum of SOA particles with other inorganic seed aerosol is similar to that displayed in Fig. 2. The absorption band of the reaction products

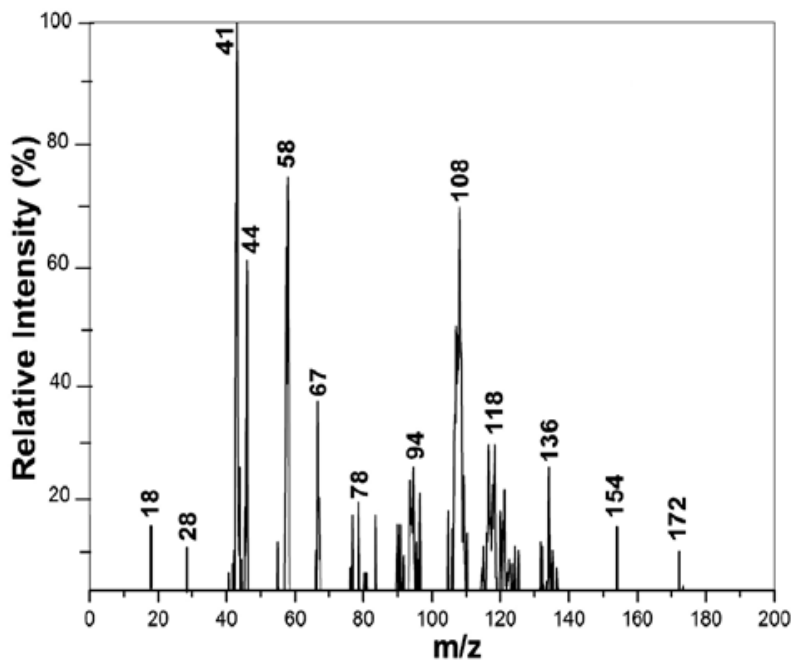

Fig. 1. Laser time-of-flight mass spectrum of toluene SOA particles in the presence of calcium chloride seed aerosol.

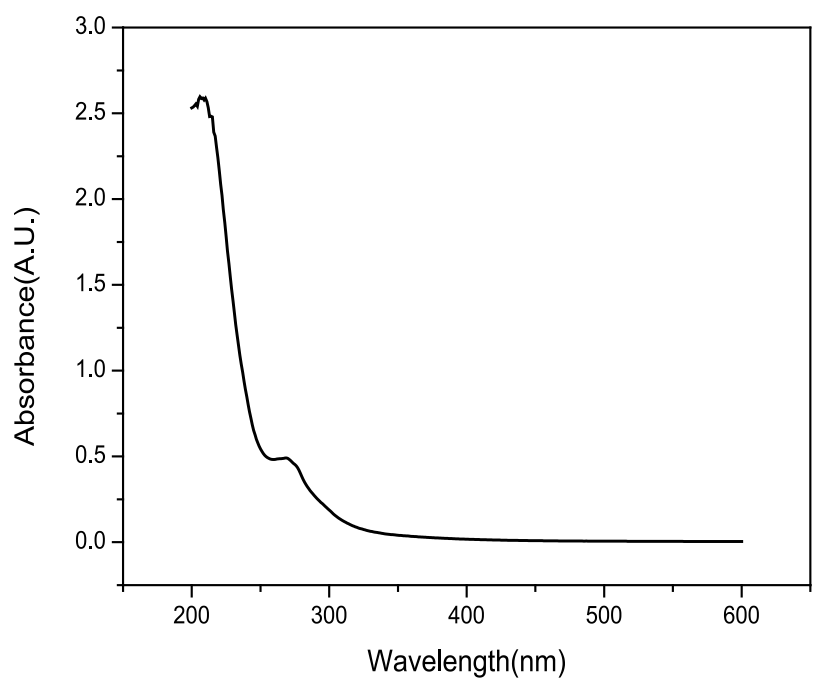

Fig. 2. UV-visible absorption spectrum of toluene SOA particles in the presence of calcium chloride seed aerosol.

at $205 \mathrm{~nm}$ is mainly the characteristic absorption of the $\mathrm{n} \rightarrow \pi^{*}$ transition of the carboxylic acid group (-COO-) in the ammonium acid products. The absorption peak at $270 \mathrm{~nm}$ is mainly due to the absorption of $\mathrm{n} \rightarrow \pi^{*}$ electronic transitions of $\mathrm{C}=\mathrm{N}$ double bonds in the nitrogen-containing imidazole compounds formed from aldehyde products such as glyoxal in the aerosol phase product reaction with $\mathrm{NH}_{3}$ [28-29]. This further verified that ammonium carboxylate and nitrogen-containing imidazole compounds are the main reaction products. According to Lambert Beer's law, the absorbance of the product solution is positively correlated with the concentration of the product solution. Therefore, the effects of inorganic seed aerosol on the nitrogencontaining organic products formed by the reaction of $\mathrm{NH}_{3}$ and the photooxidation products of toluene were analyzed by the change of absorbance of the reaction product solution at $205 \mathrm{~nm}$ and $270 \mathrm{~nm}$ in the following sections.

\section{Effects of Different Inorganic Seed Aerosol on the Formation of Nitrogen-Containing Organic Compounds}

In the reaction system of $10 \mathrm{ppm}$ toluene, $50 \mathrm{ppm}$ $\mathrm{O}_{3}, 10 \mathrm{ppm} \mathrm{NH}_{3}$, and seed aerosol concentration of $120 \mu \mathrm{g} \cdot \mathrm{m}^{-3}$, the four UV lamps were used for $2 \mathrm{~h}$, and the absorbance of the products solution at $205 \mathrm{~nm}$ and $270 \mathrm{~nm}$ after illumination are shown in Fig. 3. In the presence of inorganic seed aerosol, the absorbance at either $205 \mathrm{~nm}$ or $270 \mathrm{~nm}$ of SOA formed by the reaction of $\mathrm{NH}_{3}$ with the photooxidation products of toluene are higher than that of SOA without seed aerosol. This indicates that the presence of inorganic seed aerosol increased the content of ammonium acid and imidazole products. By comparing the absorbance values of the reaction products at $205 \mathrm{~nm}$ and $270 \mathrm{~nm}$ in the presence of five different inorganic seed aerosols, it was seen that 

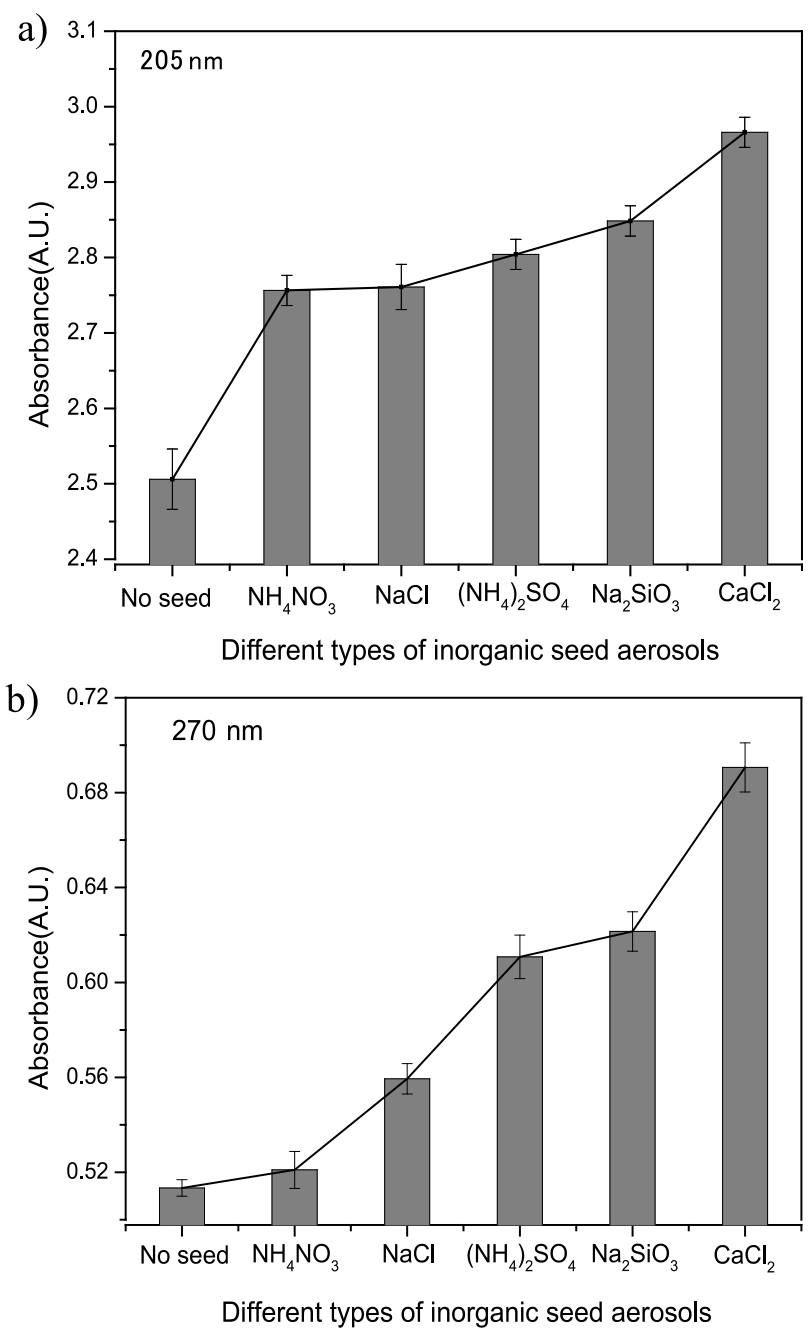

Fig. 3. Ultraviolet absorbance of SOA at a) $205 \mathrm{~nm}$ and b) $270 \mathrm{~nm}$ formed by the reaction of ammonia with the photooxidation products of toluene in the presence of different inorganic seed aerosols.

the order of promotion of strength is $\mathrm{CaCl}_{2}>\mathrm{Na}_{2} \mathrm{SiO}_{3}>$ $\left(\mathrm{NH}_{4}\right)_{2} \mathrm{SO}_{4}>\mathrm{NaCl}>\mathrm{NH}_{4} \mathrm{NO}_{3}$.

In the absence of seed aerosol, the gas phase organic products formed from the photooxidation of toluene accumulate to sufficient supersaturation to initiate homogeneous nucleation, resulting in the formation of SOA particles. When inorganic seed aerosol is present in the system, the surface area provides a good condensation center for the semi- volatile and nonvolatile products to form SOA particles. Also, these inorganic salts have a certain hygroscopic property, and the formed inorganic seed aerosol surface absorbs water vapor, and it was easy to absorb $\mathrm{NH}_{3}$ to its surface [30]. According to the experimental results of Liu et al. [7] and Zhang et al. [31], the reactions of $\mathrm{NH}_{3}$ with carbonyls are usually acid catalyzed, and the rates of gas phase reactions between $\mathrm{NH}_{3}$ and carbonyls are exceedingly slow as a thermolecular reaction would be necessary, and heterogeneous reactions occur after $\mathrm{NH}_{3}$ absorbed onto the SOA contribute to the particulate nitrogen-containing organic products. So, in the seed experiments, when the $\mathrm{OH} \bullet$ initiate the photooxidation reaction of toluene, the produced gas phase aldehyde compound and organic acid and other products condense on the surface of the inorganic seed aerosol and react with $\mathrm{NH}_{3}$ to formed ammonium acid and imidazole compounds. The presence of inorganic seed aerosol in the experiment caused the condensation and reaction of the oxidation products on the seed surface, accelerated the formation rate of SOA and increased the content of reaction products. The absorbance of the product at $205 \mathrm{~nm}$ and $270 \mathrm{~nm}$ in the presence of inorganic seed aerosol was significantly higher than that in the absence of seed aerosol. However, the five inorganic salts have different hygroscopic strengths. According to the experimental results of Wang et al. [32] and Ge et al. [12], the order of hygroscopicity was $\mathrm{CaCl}_{2}>\mathrm{Na}_{2} \mathrm{SiO}_{3}>\left(\mathrm{NH}_{4}\right)_{2} \mathrm{SO}_{4}>\mathrm{NaCl}>\mathrm{NH}_{4} \mathrm{NO}_{3} . \mathrm{CaCl}_{2}$ has the strongest moisture absorption performance. Under the same relative humidity conditions, the amount of water absorption and $\mathrm{NH}_{3}$ absorption of $\mathrm{CaCl}_{2}$ seed aerosol surface is also the largest. Thus, the content of the finally produced ammonium acid and imidazole products is the highest.

\section{Effect of Different Concentrations of Calcium Chloride Seed Aerosol on the Formation of Nitrogen-Containing Organic Products}

Inorganic seed aerosol is the center for the condensation and reaction of the photooxidation products of toluene. The concentration of the seed aerosol directly determines the size of the center area, which affects the formation rate and content of ammonium acid and imidazole compounds. Fig. 4 shows the absorbance at $205 \mathrm{~nm}$ and $270 \mathrm{~nm}$ of SOA in the presence of different concentrations of $\mathrm{CaCl}_{2}$ seed aerosol. It can be seen from Fig. 4 that the absorbance at $205 \mathrm{~nm}$ and $270 \mathrm{~nm}$ shows the similar change with the increasing aerosol concentration of $\mathrm{CaCl}_{2}$ seeds. When the concentration of $\mathrm{CaCl}_{2}$ seed aerosol is in the range of $0 \mu \mathrm{g} \cdot \mathrm{m}^{-3} \sim 120 \mu \mathrm{g} \cdot \mathrm{m}^{-3}$, the absorbance values of both bands show the significant upward trend. This means that increasing the concentration of $\mathrm{CaCl}_{2}$ seed aerosol in the reaction system can increase the content of nitrogen-containing organic compounds. When the concentration of $\mathrm{CaCl}_{2}$ seed aerosol exceeds $120 \mu \mathrm{g} \cdot \mathrm{m}^{-3}$, the two curves show the downward trend at the same time, indicating that the excessive concentration of $\mathrm{CaCl}_{2}$ seed aerosols are not favorable for the reaction to formed ammonium acid and imidazole compounds. When a certain concentration of $\mathrm{CaCl}_{2}$ seed aerosol was added to the reaction system, the gas phase semi-volatile and non-volatile products formed by the photooxidation of toluene can condense on the surface and react with $\mathrm{NH}_{3}$ to form ammonium acid and imidazole organic compounds. As the concentration of $\mathrm{CaCl}_{2}$ seed aerosol increases, the surface area that provides condensation and reaction also increases. This contributes to the absorption of $\mathrm{NH}_{3}$ and the condensation of the gas phase 
photooxidation products of toluene, thereby increasing the amount of formation of the nitrogen-containing organic compounds, that is, the change shown in Fig. 4. Since the concentrations of toluene and $\mathrm{O}_{3}$ were kept constant during the experiment, the gas phase photooxidation products produced were also constant. When the $\mathrm{CaCl}_{2}$ seed aerosol was increased to a certain concentration $\left(120 \mu \mathrm{g} \bullet \mathrm{m}^{-3}\right)$, the gas phase photooxidation products produced by photooxidation of toluene completely condensed, and then the concentration of the seed aerosol was increased, and the content of the nitrogen-containing organic compounds no longer increased. However, the relative humidity in the chamber is constant, and the higher the concentration of the seed aerosol, the less liquid water is absorbed on the surface. The ability to absorb $\mathrm{NH}_{3}$ and carbonyls on the surface of high concentrations of $\mathrm{CaCl}_{2}$ seed aerosol (more than $120 \mu \mathrm{g} \cdot \mathrm{m}^{-3}$ ) may be reduced. Thus, in the presence of the higher concentration of $\mathrm{CaCl}_{2}$ seed aerosol as shown in Fig. 4, the absorbance of the reaction product at 205 $\mathrm{nm}$ and $270 \mathrm{~nm}$ showed a downward trend.
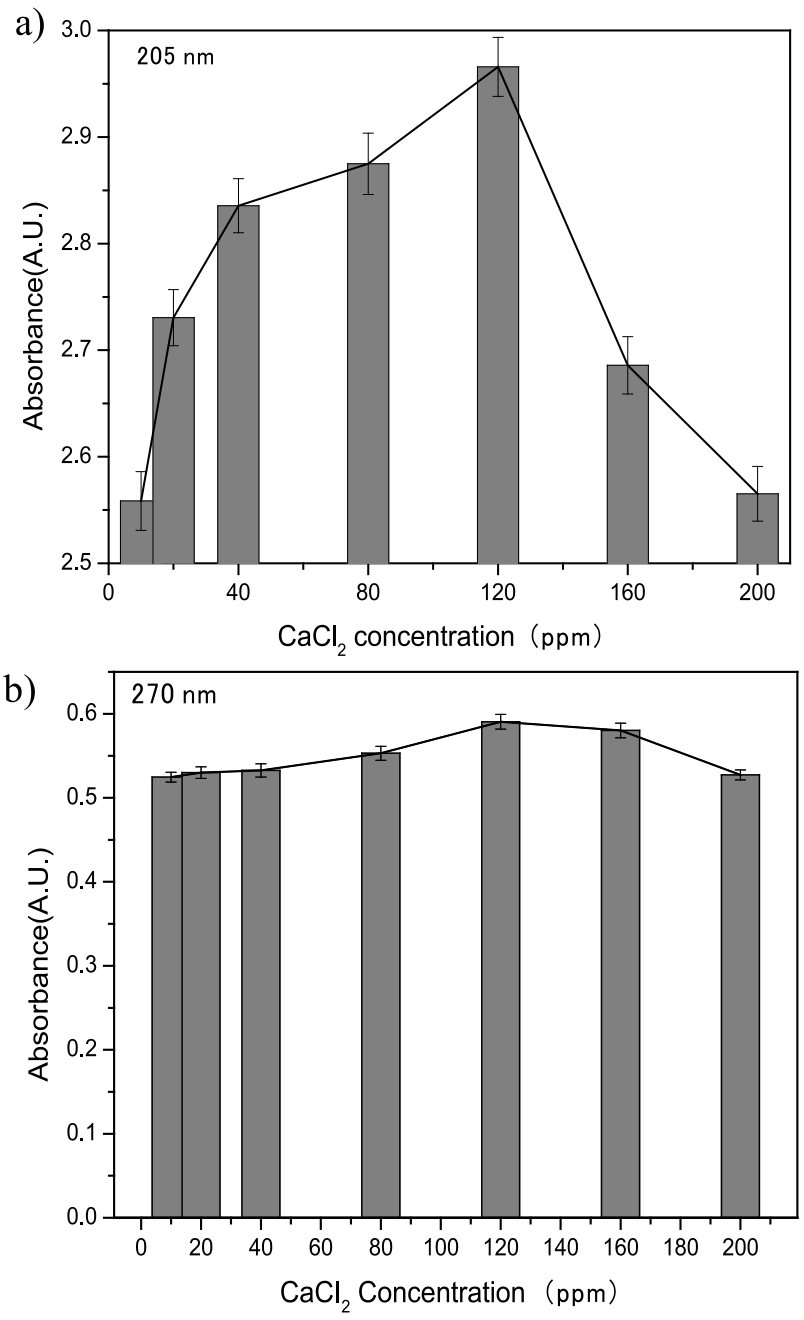

Fig. 4. Ultraviolet absorbance of SOA at a) $205 \mathrm{~nm}$ and b) $270 \mathrm{~nm}$ formed by the reaction of ammonia with the photooxidation products of toluene in the presence of calcium chloride seed aerosols of different concentrations.

\section{Effect of Different Humidity Calcium Chloride Seed Aerosol on the Formation of Nitrogen- Containing Organic Products}

The presence of water molecules affected the lifetime of atmospheric oxidants, and participated in the photochemical reaction of toluene, thereby changing the photooxidation of gaseous products [33]. Also, the presence of water molecules affected the gas phase and interface-controlled aerosol mass transfer processes, and changed the SOA formation process and chemical composition [34]. The relative deliquescent humidity of $\mathrm{CaCl}_{2}$ is $10 \%$, so during the experiment, the $\mathrm{CaCl}_{2}$ seed aerosol is always in a deliquescent state [32]. When the relative humidity is gradually increased from $37 \%$ to $87 \%$, the change trend of the absorbance values of ammonium acid and imidazole products at $205 \mathrm{~nm}$ and $270 \mathrm{~nm}$ is shown in Fig. 5. Both curves show an approximately linear downward trend with increasing relative humidity, which indicates that the relative

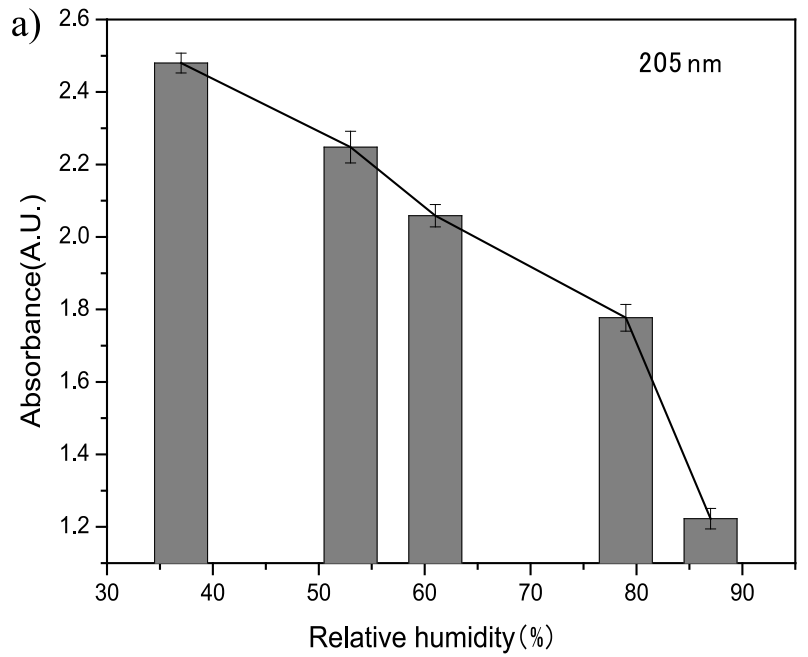

b)

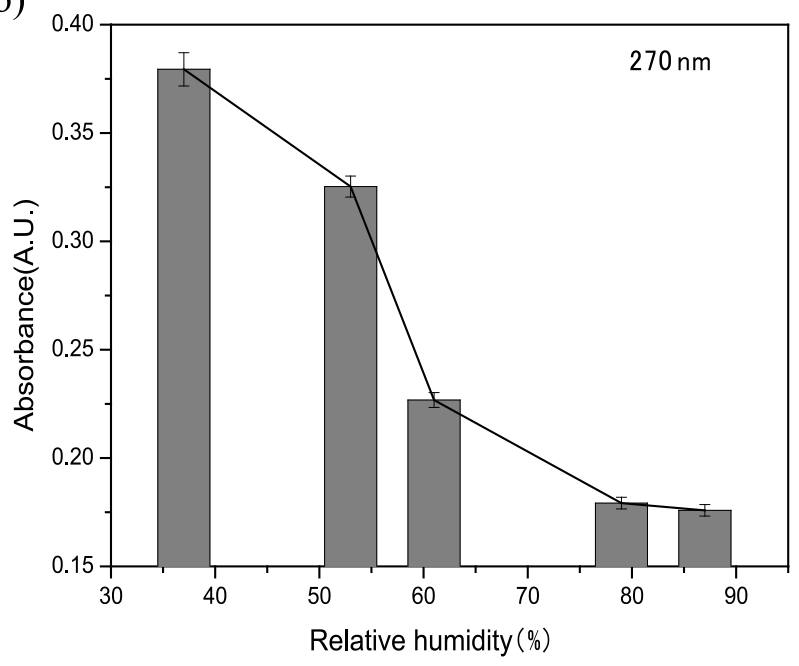

Fig. 5. Ultraviolet absorbance of SOA at a) $205 \mathrm{~nm}$ and b) $270 \mathrm{~nm}$ formed by the reaction of ammonia with the photooxidation products of toluene in the presence of calcium chloride seed aerosols of different relative humidities. 
humidity is negatively correlated with the absorbance of the reaction product. The presence of water molecules is detrimental to the formation of nitrogen-containing organic compounds.

The experimental results of Wang et al. [35] and $\mathrm{Hu}$ et al. [36] show that the rate constant of $\mathrm{O}_{3}$ wall loss increases with the increasing relative humidity, and there is a significant linear relationship between them. In addition, the excessive presence of water molecules competes with $\mathrm{O}_{3}$ for the light source, and $\mathrm{OH} \cdot$ can collision annihilation with water molecules, resulting in a significant decrease in the concentration of $\mathrm{OH}^{\bullet}$ produced by photolysis of $\mathrm{O}_{3}$ as the relative humidity increases [37-38]. Therefore, with the gradual increase of relative humidity in the chamber, the wall deposition effect of $\mathrm{O}_{3}$ is more significant, and the $\mathrm{OH} \cdot$ generated by photolysis is gradually reduced. The gas phase

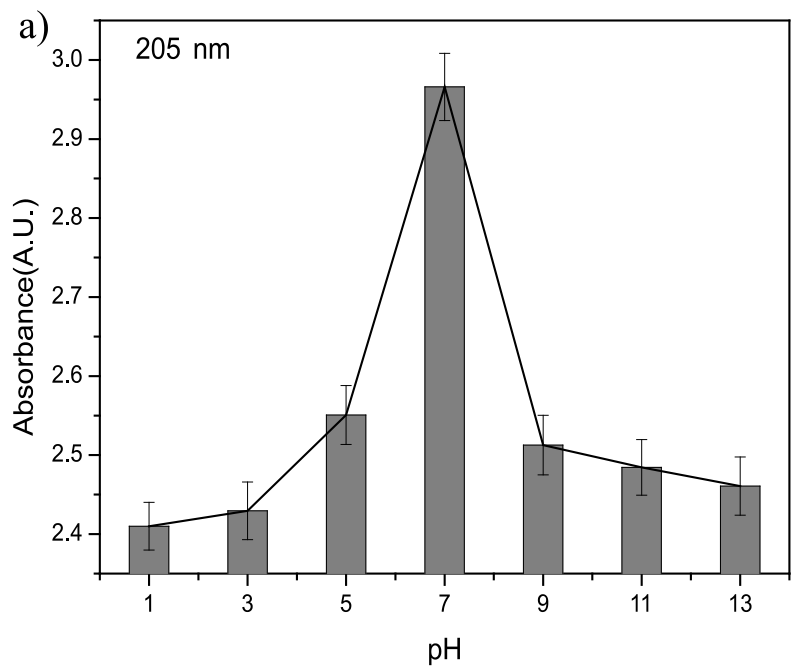

b)

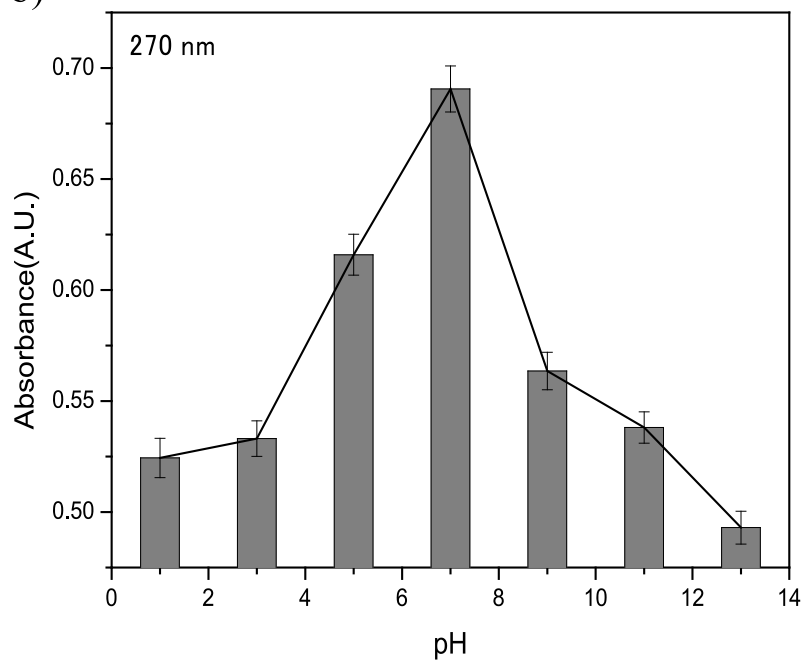

products produced by the photooxidation of toluene

Fig. 6. Ultraviolet absorbance of SOA at a) $205 \mathrm{~nm}$ and b) $270 \mathrm{~nm}$ formed by the reaction of ammonia with the photooxidation products of toluene in the presence of calcium chloride seed aerosols of different $\mathrm{pH}$. are also reduced, thereby inhibiting the formation of nitrogen-containing organic compounds. In addition, as the relative humidity increases, the $\mathrm{CaCl}_{2}$ seed aerosol will increase in particle diameter due to its strong hygroscopic property, which is beneficial to the absorption of $\mathrm{NH}_{3}$ and the coagulation and reaction of gaseous photooxidation products of toluene. However, the increase in particle size caused by the increase in relative humidity would further enhance the wall deposition effect of the particles, eventually resulting in a decrease in the collected particulate matter and the decrease in the absorbance of the measured product solution.

\section{Effect of Different Acidity of Calcium Chloride Seed Aerosol on the Formation of Nitrogen- Containing Organic Products}

In the actual atmospheric environment, seed aerosols from different sources have different acidities. The experiment used $\mathrm{CaCl}_{2}$ solutions with different $\mathrm{pH}$ values to simulate seed aerosols with different acidity. As can be seen from Fig. 6, when the $\mathrm{pH}=7$ of the solution, the absorbance at $205 \mathrm{~nm}$ and $270 \mathrm{~nm}$ is the largest, at $\mathrm{pH}=1$ and 13, the absorbance at $205 \mathrm{~nm}$ and $270 \mathrm{~nm}$ is small. This indicates that under the conditions of strong acid and alkaline, it is not favorable to the formation of ammonium acid and imidazole products. The weakly acidic conditions favor the formation of nitrogen-containing organic compounds, and the content of the products gradually increases with the increasing $\mathrm{pH}$ value. While the weak alkaline condition restricts the formation of nitrogen-containing organic compounds, the content of the product gradually decreases with the increasing $\mathrm{pH}$ value. This is basically consistent with the experimental results of Maxut et al. [39], who performed the yield of imidazole compounds formed from the reaction of glyoxal with $\mathrm{NH}_{4}^{+}$; more target products were obtained in the neutral environment of $\mathrm{pH}=7$.

Under strong acidic conditions, after the $\mathrm{CaCl}_{2}$ seed aerosol absorbs $\mathrm{NH}_{3}$, hydrogen ions $\left(\mathrm{H}^{+}\right)$react with it to form ammonium ions $\left(\mathrm{NH}_{4}^{+}\right)$. Since the formed $\mathrm{NH}_{4}^{+}$ is the weak acid, it cannot react with the condensed organic acid to form ammonium acid. According to the experimental results of Liu et al. [7] and our group [23-24], the hydration of the dialdehyde compound and the reaction with $\mathrm{NH}_{3}$ to form the tetraol and diimine products are important precursors for the formation of imidazole products. Since the reactivity of $\mathrm{NH}_{4}^{+}$ is less than that of $\mathrm{NH}_{3}$, the rate of $\mathrm{NH}_{3}$ reaction with the condensed dialdehyde compound to form diimine is low, and the yield is small, resulting in the decrease of imidazole products. Therefore, under strong acid conditions, it is not favorable to the formation of nitrogen-containing organic compounds. In the acidic range of $\mathrm{pH}<7$, the absorbance of the reaction product solution at $205 \mathrm{~nm}$ and $270 \mathrm{~nm}$ gradually increases with increasing $\mathrm{pH}$. Under alkaline conditions, excess 
hydroxide ions $\left(\mathrm{OH}^{-}\right)$would undergo the acid-based neutralization reaction with the condensed organic acid to reduce the yield of ammonium acid. At the same time, excess $\mathrm{OH}^{-}$inhibits the hydration of the dialdehyde compounds to form the tetraol products, thereby reducing the content of the imidazole products [39]. Therefore, in the alkaline range, the absorbance of the reaction product solution at $205 \mathrm{~nm}$ and $270 \mathrm{~nm}$ decreases as the $\mathrm{pH}$ increases. It is worth noting that few $\mathrm{Na}^{+}$ions were introduced in $\mathrm{CaCl}_{2}$ seed aerosol after adjusting the alkalinity of $\mathrm{CaCl}_{2}$ solution with $\mathrm{NaOH}$. However, the presence of $\mathrm{OH}^{-}$in the $\mathrm{CaCl}_{2}$ seed aerosol decreases the content of nitrogen-containing organic products [39]. $\mathrm{Na}^{+}$ions are not involved in the formation of nitrogen-containing organic products, and therefore do not affect the aforementioned experimental results.

\section{Conclusions}

According to the difference between the composition and physicochemical properties of the photooxidation products of $\mathrm{NH}_{3}$ and toluene in the presence of seed aerosol according to ALTOFMS spectra and UVVis spectra, the effects of inorganic seed aerosol on the nitrogen-containing organic compounds formed by the reaction was qualitatively characterized by the UV-visible spectrum. The inorganic seed aerosol has large surface area and can be used as the condensation center of the gas phase products of the photooxidation of toluene and the reaction center with $\mathrm{NH}_{3}$. Thereby the formation of nitrogen-containing organic products such as ammonium acid and imidazoles are promoted. The order of promotion is $\mathrm{CaCl}_{2}>\mathrm{Na}_{2} \mathrm{SiO}_{3}>\left(\mathrm{NH}_{4}\right)_{2} \mathrm{SO}_{4}>$ $\mathrm{NaCl}>\mathrm{NH}_{4} \mathrm{NO}_{3}$. The concentration of ammonium acid and imidazole products increases with the increasing concentration and acidity of $\mathrm{CaCl}_{2}$ seed aerosol, but decreases with the increase of relative humidity. However, when the $\mathrm{CaCl}_{2}$ seed aerosol is alkaline, $\mathrm{OH}^{-}$ will undergo the acid-base neutralization reaction with the condensed organic acid and inhibit the hydration of the dialdehyde compound to form tetraol product, thus being disadvantageous for the formation of the nitrogencontaining organic products. Nitrogen-containing organic compounds can absorb solar radiation and reduce visibility, and are the important components of atmospheric brown carbon. On this basis, subsequent experiments can be carried out on the measurements of extinction and scattering coefficient of SOA particles in the presence of $\mathrm{NH}_{3}$ and inorganic seed aerosol.

\section{Acknowledgements}

Our work was supported by the National Natural Science Foundation of China (Nos. 41575118, 41305109), and the Outstanding Youth Science Foundation of Fujian Province of China (No. 2015J06009).

\section{Conflict of Interest}

The authors declare no conflict of interest.

\section{Reference}

1. YANG B., MA P.K., SHU J.N., ZHANG P., HUANG J.Y., ZHANG H.X. Formation mechanism of secondary organic aerosol from ozonolysis of gasoline vehicle exhaust. Environ. Pollut. 234, 960, 2018.

2. SALEH R., DONAHUE N.M., ROBINSON A.L. Time scales for gas-particle partitioning equilibration of secondary organic aerosol formed from alpha-pinene ozonolysis. Environ. Sci. Technol. 47 (11), 5588, 2013.

3. SUN K., TAO L., MILLER D.J., PAN D., GOLSTON L.M., ZONDLO M.A., GRIFFIN R.J., WILLIAN W.H., LEONG Y.J., YANG M.Y.M., ZHANG Y., MAUZERALL D.L., ZHU T. Vehicle emissions as an important urban ammonia source in the united states and china. Environ. Sci. Technol. 51 (4), 2472, 2017.

4. PAULOT F., JACOB D.J., PINDER R.W., BASH J.O., TRAVIS K., HENZE D.K. Ammonia emissions in the United States, European Union, and China derived by high-resolution inversion of ammonium wet deposition data: Interpretation with a new agricultural emissions inventory (MASAGE_NH $\mathrm{N}_{3}$ ). J. Geophys. Res. -Atmos. 119 (7), 4343, 2014.

5. CHU B.W., ZHANG X., LIU Y.C., HE H., SUN Y.L., JIANG J.K., LI J.H., HAO J.M. Synergetic formation of secondary inorganic and organic aerosol: effect of $\mathrm{SO}_{2}$ and $\mathrm{NH}_{3}$ on particle formation and growth. Atmos. Chem. Phys. 16 (22), 14219, 2016.

6. CHENG Y.F., ZHENG G.J., WEI C., MU Q., ZHENG B., WANG Z.B., GAO M., ZHANG Q., HE K.B., CARMICHAEL G., PöSCHL U., SU H. Reactive nitrogen chemistry in aerosol water as a source of sulfate during haze events in China. Sci. Adv. 2 (12), el601530, 2016.

7. LIU Y., LIGGIO J., STAEBLER R., LI S.M. Reactive uptake of ammonia to secondary organic aerosols: kinetics of organonitrogen formation. Atmos. Chem. Phys. 15 (23), 13569, 2015.

8. HUANG M.Q., XU J., CAI S.Y., LIU X.Q., HU C.J., GU X.J., ZHAO W.X., FANG L., ZHANG W.J. Chemical analysis of particulate products of aged 1,3,5-trimethylbenzene secondary organic aerosol in the presence of ammonia. Atmos. Pollut. Res. 9 (1), 146, 2018.

9. TRAINIC M., ABO R. A., LAVI A., FLORES M., RUDICH Y. The optical, physical and chemical properties of the products of glyoxal uptake on ammonium sulfate seed aerosols. Atmos. Chem. Phys. 11 (18), 9697, 2011.

10. LASKIN A., LASKIN J., NIZKORODOV S.A. Chemistry of atmospheric brown carbon. Chem. Rev. 115 (10), 4335, 2015.

11. BEARDSLEY R., JANG M., ORI B., IM Y., DELCOMYN C.A., WITHERSPOON N. Role of sea salt aerosols in the formation of aromatic secondary organic aerosol: yields and hygroscopic properties. Environ. Chem. 10 (3), 167, 2013.

12. GE S.S., XU, Y.F., JIA L. Effects of inorganic seeds on secondary organic aerosol formation from photochemical oxidation of acetone in a chamber. Atmos. Environ. 170, 205, 2017.

13. HUANG M.Q., HAO L.Q., CAI S.Y., GU X.J., ZHANG W.X., HU C.J., WANG Z.Y., FANG L., ZHANG W.J. 
Effects of inorganic seed aerosols on the particulate products of aged 1,3,5-trimethylbenzene secondary organic aerosol. Atmos. Environ. 152, 490, 2017.

14. HUANG M.Q., ZHANG J.H., CAI S.Y., LIAO Y.M., ZHAO W.X., HU C.J., GU X.J., FANG L., ZHANG W.J. Characterization of particulate products for aging of ethylbenzene secondary organic aerosol in the presence of ammonium sulfate seed aerosol. J. Environ. Sci. 47, 219, 2016.

15. EDNEY E.O., DRISCOLL D.J., SPEER R.E., WEATHERS W.S., KLEINDIENST T.E., LI W., SMITH D.F. Impact of aerosol liquid water on secondary organic yields of irradiated toluene/propylene/ $\mathrm{NOx} /\left(\mathrm{NH}_{4}\right)_{2} \mathrm{SO}_{4}$ /air mixtures. Atmos. Environ. 34, 3907, 2000.

16. HAO L.Q., WANG Z.Y., HUANG M.Q., FANG L., ZHANG W.J. Effects of seed aerosols on the growth of secondary organic aerosols from the photooxidation of toluene. J. Environ. Sci. 19 (6), 704, 2007.

17. KROLL J.H., CHAN A.W.H., NG N.L., FLAGAN R C., SEINFELDB J.H. Reactions of semivolatile organics and their effects on secondary organic aerosol formation. Environ. Sci. Technol. 41 (10), 3545, 2007.

18. LU Z.F., Hao J.M., TAKEKAWA H., HU L.H., Li J.H. Effect of high concentrations of inorganic seed aerosols on secondary organic aerosol formation in the m-xylene/NOx photooxidation system. Atmos. Environ. 43, 897, 2009.

19. CHU B.W., HAO J.M., TAKEKAWA H., LI J.H., WANG K., JIANG J.K. The remarkable effect of $\mathrm{FeSO}_{4}$ seed aerosols on secondary organic aerosol formation from photooxidation of $\alpha$-pinene/NOx and toluene/NOx. Atmos. Environ. 55, 26, 2012.

20. ZHANG R.J., HAN Z.W., SHEN Z.X., CAO J.J. Continuous measurement of number concentrations and elemental composition of aerosol particles for a dust storm event in Beijing. Adv. Atmos. Sci. 25 (1), 89, 2008.

21. SUN Y.L., ZHUANG G.S., TANG, A.H., WANG Y., AN Z.S. Chemical characteristics of $\mathrm{PM}_{2.5}$ and $\mathrm{PM}_{10}$ in hazefog episodes in Beijing. Environ. Sci. Technol. 40 (10), 3148, 2006.

22. HUANG M.Q., Lin Y.H., HUANG X.Y., LIU X.Q., GUO X.Y., Hu C.J., ZHAO W.X., Gu X.J., FANG L., ZHANG W.J. Experimental study of particulate products for aging of 1,3,5-trimethylbenzene secondary organic aerosol. Atmos. Pollut. Res. 6 (2), 209, 2015.

23. HUANG M.Q., XU J., CAI S.Y., LIU X.Q., HU C,J., GU X,J., ZHAO W.X., FANG L., ZHANG W.J. Mass spectral analysis of the aged 1,3,5-trimethylbenzene secondary organic aerosol in the presence of ammonium sulfate seeds. Pol. J. Environ. Stud. 26 (4), 1531, 2017.

24. HUANG M.Q., XU J., CAI S.Y., LIU X.Y., ZHAO W.X., HU C.J., GU X.J., FANG L., ZHANG W.J. Characterization of brown carbon constituents of benzene secondary organic aerosol aged with ammonia. J. Atmos. Chem. 75 (2), 205, 2018.

25. LI L.J., TANG P., NAKAO S., KACARAB M., COCKER III.D.R. Novel approach for evaluating secondary organic aerosol from aromatic hydrocarbons: unified method for predicting aerosol composition and formation. Environ. Sci. Technol. 50 (12), 6249, 2016.

26. GENTNER D.R., JATHAR S.H., GORDON T.D., BAHREINI R., DAY D.A., HADDAD I.E., HAYES P.L.,
PIEBER S.M., PLATT S.M., GOUW J.D., GOLDSTEIN A.H., HARLEY R.A., JIMENEZ J.L., PREVOT A.S.H., ROBINSON A.L. Review of urban secondary organic aerosol formation from gasoline and diesel motor vehicle emissions. Environ. Sci. Technol. 51 (3), 1074, 2017.

27. SAREEN N., WAXMAN E.M., TURPIN B.J., VOLKAMER R., CARLTON A.G. Potential of aerosol liquid water to facilitate organic aerosol formation: assessing knowledge gaps about precursors and partitioning. Environ. Sci. Technol. 51 (6), 33227, 2017.

28. GALLOWAY M.M., CHHABRA P.S., CHAN A.W.H., SURRATT J.D., FLAGAN R.C., SEINFELD J.H., KEUTSCH F.N. Glyoxal uptake on ammonium sulphate seed aerosol: reaction products and reversibility of uptake under dark and irradiated conditions. Atmos. Chem. Phys. 9 (10), 3331, 2009.

29. LEE A.K.Y., ZHAO R., LI R, LIGGIO J., LI M.S., ABBATT J.P.D. Formation of light absorbing organonitrogen species from evaporation of droplets containing glyoxal and ammonium sulfate. Environ. Sci. Technol. 47 (22), 12819, 2013.

30. NA K., SONG C., SWITZER C., COCKER D.R. Effect of ammonia on secondary organic aerosol formation from $\alpha$-Pinene ozonolysis in dry and humid conditions. Environ. Sci. Technol. 41 (17), 6096, 2007.

31. ZHANG R., WANG G., GUO S., ZAMORA, M.L., YING Q., LIN Y., WANG W.G., HU M., WANG Y. Formation of urban fine particulate matter. Chem. Rev. 115 (10), 3803, 2015.

32. WANG X. The study on hygroscopic properties of the aerosols. Beijing: Chin. Res. Acad. Environ. Sci. 2010.

33. FAUST J.A., WONG J.P.S., LEE A.K.Y., ABBATT J.P.D. Role of aerosol liquid water in secondary organic aerosol formation from volatile organic compounds. Environ. Sci. Technol. 51 (3), 1405, 2017.

34. COCKER III.D.R., CLEGG S.L., FLAGAN R.C., SEINFELE J.H. The effect of water on gas-particle partitioning of secondary organic aerosol: Part II. $m$-xylene and 1,3,5-trimethylbenzene photooxidation systems. Atmos. Environ. 35 (35), 6073, 2001.

35. WANG Y.J., LUO H., JIA L., GE S.S. Effect of particle water on ozone and secondary organic aerosol formation from benzene- $\mathrm{NO}_{2}-\mathrm{NaCl}$ irradiations. Atmos. Environ. 140, 386, 2016.

36. HU G.S., XU Y.F., JIA L. Effects of relative humidity on the characterization of a photochemical smog chamber. J. Environ. Sci. 23 (12), 2013, 2011.

37. ZHANG C.Y., MA Y.L. Experimental study on $\mathrm{UV}_{254 \mathrm{~nm}+185 \mathrm{~nm}}$ phtotodegradation of gaseous toluene. Chin. Environ. Sci. 31 (06), 898, 2011.

38. XU J., HUANG M.Q., FENG Z.Z., CAI S.Y., ZHAO W.X., HU C.J., GU X.J., ZHANG W.J. Experimental study the effects of ammonia on the formation and chemical composition of toluene secondary organic aerosol. Acta Sci Circums. 38 (8), 3243, 2018.

39. MAXUT A., NOZIERE B., FENET B., MECHAKRA H. Formation mechanism and yield of small imidazoles from reactions of glyoxal with $\mathrm{NH}_{4}^{+}$in water at neutral $\mathrm{pH}$. Phys. Chem. Chem. Phys. 17 (31), 20416, 2015. 
